\title{
Introduction
}

\section{Karl Socher}

The creation of international institutions after the Second World War had the aim of inducing economic growth and reducing poverty in the industrialised and developing countries by freezing markets for goods, services and capital from restrictions and creating a stable international monetary system. Later, environmental protection became an important aim and, after the breakdown of planned economies in socialist countries, liberalisation, deregulation and privatisation ('Washington Consensus') were implemented in the transition economies. In this process of globalisation, multinational enterprises (MNEs) have become the most important actors in the global markets.

The aim of the second International CSI Conference was to discuss the controversial questions raised by critical economists as well as non-governmental organisations (NGOs) concerning the power and influence of today's global market players. One question was whether the activities of MNEs are in conformity with the aims of the global international institutions: economic growth, development, reduction of poverty and protection of the environment. Do their managements take into account negative effects of their activities? Another question was whether market or government failures prevent countries achieving their aims, so that global international institutions have to act and have to be adapted to eliminate these failures in order to minimise the negative effects without hampering the positive effects of the activities of MNEs.

\section{CORPORATE GOVERNANCE OF MNES}

In Chapter 1, John-ren Chen refers to the tasks of governments to correct market failures (especially by the production of public goods and by internalising externalities) and to create a framework for good corporate governance. These two tasks cannot be fulfilled by sovereign states alone, because the activities of MNEs and NGOs go beyond borders and a good corporate governance system is important for an efficient resource allocation and a stable financial architecture. 
It is a task for international institutions to spread knowledge about corporate governance rules especially to developing and transition countries and to ascertain that corporate governance of MNEs accords with these rules. Chen discusses the different aspects of a good corporate governance system especially as they are incorporated in the OECD's Principles of Corporate Governance. He concludes that, in the dynamic global economy, corporations have to innovate and adapt their governance practices, and similarly the legal and regulatory frameworks have to be adjusted to the new needs of the community.

John H. Dunning, giving the 'Böhm-Bawerk Lecture', spoke on the moral challenge of global capitalism. He proposes a responsible global capitalism as a means towards a richer, healthier and more meaningful lifestyle and not as an end in itself. In order to move towards this inclusive and acceptable global capitalism, the organisational structures of markets, governments and international institutions needs to be reconfigured. To achieve responsible global capitalism, an acceptable moral ecology is needed underpinning the attitudes, motives and behaviour of its individuals and institutions. This ecology needs a continual reappraisal and careful nurturing by the appropriate incentives and enforcement mechanism.

The upgrading of moral attitudes and values could be reached either by a bottom-up approach (from NGOs and so on) or from a top-down approach (for instance the Global Compact approach by the UN). Both approaches could be guided by religious revelations. Dunning refers to his 1998 proposal that an annual meeting of a group of the world's religious leaders should be convened. As an alternative course of action he proposed in this lecture a UN Commission on the Moral and Ethical Implications of Globalisation.

He ends in a plea to all international business scholars to integrate the moral and ethical dimension in their analysis and seek to explain how global capitalism might work to the greater good of a larger number of people throughout the world.

Hans Hinterhuber, Kurt Matzler, Harald Pechlaner and Birgit Renzl first describe the different corporate governance systems in the USA, Great Britain, Germany and Japan. They conclude that the 'power-base' for legitimising the strategy of a corporation is larger, more complex and more political in Europe than in the USA. Therefore, in a European corporation, not only the priorities of shareholders but also those of the stakeholders, like the employees, the government and the environment, are included in the strategies. This example should be followed by MNEs in their own interest. The many rules for corporate governance systems developed by international institutions (the UN Code of Conduct, UN Global Compact, ICC Guidelines, OECD Guidelines and others) do not have much impact on the governance of MNEs, because they have only voluntary compliance and are not enforced by many governments. 
However they have been useful for the codes of ethics which many firms have formulated, serving all stakeholders' interests.

\section{MERGER CONTROL OF MNES}

Oliver Budzinski discusses the problem of cross-border merger control, which has become widespread during the recent globalisation process, with megamergers forming large global MNEs. It needs cross-border merger governance by an international institutional arrangement to coordinate the national merger controls.

However neither centralism, in the form of a uniform global competition rule and enforcement, nor decentralism can adequately cope with the problem. Centralism inhibits learning and innovations, decentralism lacks consistency and leads to conflicts between the different national merger controls.

Budzinski proposes a multi-level system of institutions, which could probably emerge from the International Competition Network (ICN) which was founded in 2001 by an initiative from the USA and is supported by the EU against a centralised solution of the WTO.

\section{TAXES ON MNES}

Francesca Gastaldi and Maria Grazia Pazienza try to find out whether MNEs in the Italian textile and clothing sector pay fewer taxes than local enterprises. Because capital mobility has become higher and taxes on capital are different, MNEs may try to avoid high taxation by shifting profits to low-tax countries.

On the other hand, governments may try to compete with lower taxation of foreign capital to attract investments. International organisation (such as the OECD) try to restrict this tax competition, because it could lead to a beggarmy-neighbour policy. Gastaldi and Pazienza give empirical evidence that domestic firms pay higher taxes than MNEs, which have a lower profit rate, suggesting that they aim at minimising the tax burden. However, the authors do not find clear evidence for profit shifting, either by leverage or by transfer pricing practices.

\section{MNE WAGES AND LABOUR STANDARDS}

Matthias Busse challenges the conventional perception that MNEs set up in lower labour standard countries. To the contrary, he can show that the level of 
labour standards is positively associated with a foreign direct investment (FDI) inflow. Then he discusses the arguments for and against internationally binding rules for labour standards. He proposes not to set binding rules through international organisations, because they may be unfair to guiltless workers and firms and therefore wasteful. He considers that product labelling is a more effective approach, which allows for voluntary commitments. For international institutions like the ILO there remains the task of monitoring the observance of labour standards and its violations.

Vuduyagi Balasubramanyam and David Sapsford state some propositions about the relationship between MNEs and wages: for instance, that FDI is attracted by low-wage locations, foreign firms pay relatively higher wages than domestic firms, especially to skilled workers, and disperse production across countries, thereby fragmenting the labour market. The MNEs become monopsonists in certain sectors of the international labour market and distort the resource allocation even within the domestic economies. This monopsonistic power of MNEs cannot be controlled by the legislation of national governments.

The authors propose to create a multinational trade union and, because the transnational collective bargaining may not reach a pareto-efficient allocation, to create a Transnational Labour Court to oversee this bargaining.

\section{MARKET ENTRY OF MNES}

Brian Portelli finds that liberalisation of FDI in least developed countries introduces new economic actors, the MNEs, which are supposed to act as an engine of growth by increasing the competitiveness of indigenous resources and capabilities. But, as the author shows, this requires a major restructuring of the existing economic system to increase the absorptive capacities and the capabilities of the country. An FDI-led upgrading of the host country system needs many steps in a virtuous interactive process between MNEs and the host economic agents.

Klaus Weiermair and Mike Peters first describe the rise of MNEs in tourism and the theories which try to explain this rise. They show to what extent MNEs may be capable of outcompeting the small and medium-sized enterprises in alpine tourism in Austria, and give some indications for economic policy intervention on behalf of the small and medium enterprises: government sponsoring of education and training to correct market failures in education, a national and international competition policy against monopolistic pricing of MNEs, and development of new forms of organisations for cooperation between small and medium enterprises and sponsoring of innovations. 


\section{INTERNATIONAL FINANCIAL INSTITUTIONS AND FINANCIAL MARKET STABILITY}

Daniel Daianu, in a wide-ranging discussion of temporary problems of the world economy, warns of fundamentalism in policy making and asks for more creative policies which acknowledge particular circumstances.

He cites many examples in developed, developing and transition countries. At the level of the international financial institutions, failures in development policy had been made by applying the 'Washington Consensus' rigidly, but there is not only one way or one best practice. The backlash against globalisation is a reminder of the perils of such monolithic policies. Free trade and capital flows are not in all circumstances conducive to economic growth and stability.

New theories show us the importance of multiple equilibria and undermine some constructs of neoclassical economics. Also the different institutional set-ups in transition countries make clear that there has to be a wide variety and creativity of policy making.

Klaus Liebscher, Governor of the Oesterreichische Nationalbank (Central Bank of Austria) deals with the measures used in the EU and global financial institutions to increase the stability of financial markets.

National governments and national banks cannot handle the necessary governance of world financial markets. Financial stability is a global public good. Most of the financial crises of the past decades were caused by political interferences in the supervisory process, weak regulations and lack of public sector accountability and transparency.

Liebscher discusses the measures of the European Monetary Union of Basle II and the Financial Sector Assessment Program of the IMF as good examples of international efforts at coordination and cooperation to avoid financial crises in the future. There are also private initiatives of self-regulation, for instance the International Council of Securities Associations (ICSA).

The central pillars of the international financial system (institutions, markets and the infrastructure) have been strengthened in recent times, but further progress has to be made in implementing many practices which are already recognised as desirable. This last sentence could be said to be the 'Leitmotiv' for most of the authors of this book, who discussed and proposed many initiatives for a better corporate governance of MNEs and reforms for international institutions to achieve more growth and stability and less poverty in the world economy. 